\title{
Radiolarian assemblages in the shelf area of the East China Sea and Yellow Sea and their ecological indication of the Kuroshio Current derivative branches
}

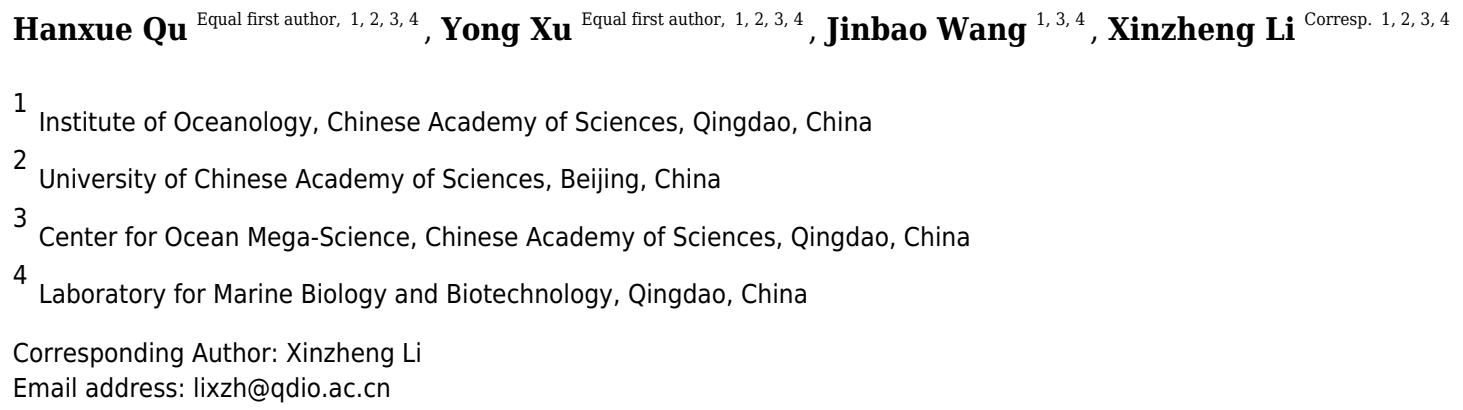

We analyzed the radiolarian assemblages of 59 surface sediment samples collected from the Yellow Sea and East China Sea of the northwestern Pacific. In the study region, the Kuroshio Current and its derivative branches exerted a crucial impact on radiolarian composition and distribution. Radiolarians in the Yellow Sea shelf showed a quite low abundance as no tests were found in 15 of 25 Yellow Sea samples. Radiolarians in the East China Sea shelf could be divided into three regional groups: the East China Sea north region group, the East China Sea middle region group, and the East China Sea south region group. The results of the redundancy analysis suggested that the Sea Surface Temperature and Sea Surface Salinity were primary environmental variables explaining species-environment relationship. The gradients of temperature, salinity, and species diversity reflect the powerful influence of the Kuroshio Current in the study area. 


\section{Radiolarian assemblages in the shelf area of the East}

2 China Sea and Yellow Sea and their ecological

3 indication of the Kuroshio Current derivative branches

Hanxue $\mathrm{Qu}^{1,2,3,4}$, Yong $\mathrm{Xu}^{1,2,3,4}$, Jinbao Wang ${ }^{1,3,4}$, Xinzheng $\mathrm{Li}^{1,2,3,4}$

$7{ }^{1}$ Institute of Oceanology, Chinese Academy of Sciences, 7 Nanhai Road, Qingdao 266071,

8 China

$9 \quad{ }^{2}$ University of Chinese Academy of Sciences, Beijing 100049, China

$10{ }^{3}$ Center for Ocean Mega-Science, Chinese Academy of Sciences, 7 Nanhai Road,

11 Qingdao, 266071, China

$12{ }^{4}$ Laboratory for Marine Biology and Biotechnology, Pilot National Laboratory for

13 Marine Science and Technology (Qingdao), 1 Wenhai Road, Qingdao 266237, China

14

15 Corresponding Author:

16 Xinzheng Li

177 Nanhai Road, Qingdao, 266071, China

18 Email address: lixzh@qdio.ac.cn 


\section{Abstract}

21 We analyzed the radiolarian assemblages of 59 surface sediment samples collected from the

22

23

24

25

26

27

28

29

30

31

32

33

34

35

36

37

38

39

40

41

42

43

44

45

46

47

48

49

50

51

52

53

54

55

56

57

58

59

Yellow Sea and East China Sea of the northwestern Pacific. In the study region, the Kuroshio

Current and its derivative branches exerted a crucial impact on radiolarian composition and distribution. Radiolarians in the Yellow Sea shelf showed a quite low abundance as no tests were found in 15 of 25 Yellow Sea samples. Radiolarians in the East China Sea shelf could be divided into three regional groups: the East China Sea north region group, the East China Sea middle region group, and the East China Sea south region group. The results of the redundancy analysis suggested that the Sea Surface Temperature and Sea Surface Salinity were primary environmental variables explaining species-environment relationship. The gradients of temperature, salinity, and species diversity reflect the powerful influence of the Kuroshio Current in the study area.

\section{Introduction}

Polycystine Radiolaria (hereafter Radiolaria), with a high diversity of 1192 Cenozoic fossil to Recent species, are a crucial group of marine planktonic protists (Lazarus et al., 2015; Suzuki, 2016). Living Radiolaria are widely distributed throughout the shallow-to-open oceans (Lombari \& Boden, 1985; Wang, 2012), and a proportion of their siliceous skeletons settle on the seafloor after death (Takahashi, 1981; Yasudomi et al., 2014). The distribution of Radiolaria in a given region is associated with the pattern of water mass, such as temperature, salinity and nutrients (Abelmann \& Nimmergut, 2005; Anderson, 1983; Hernández - Almeida et al., 2017). The East China Sea (ECS) and Yellow Sea (YS) are marginal seas of the northwestern Pacific (Xu et al., 2011). The two regions are divided by the line connecting the northern tip of the mouth of the Changjiang and the southern tip of the Jeju Island (Jun, 2014). Hydrographic conditions of the shelf area of both the ECS and YS, where the depth is generally less than 100 meters, vary remarkably with the season (Qi, 2014). Generally, the annual sea surface temperature (SST) and sea surface salinity (SSS) show a decreasing trend from the southeast to northwest in study area (Fig. 1).

The Kuroshio Current originates from the Philippine Sea, flows through the ECS, and afterwards forms the Kuroshio Extension (Hsueh, 2000; Qiu, 2001). The Kuroshio Current and its derivative branch-the Taiwan Warm Current (TWC), form the main circulation systems in the ECS shelf area, while the Yellow Sea Warm Current, one derivative branch of the Kuroshio Current, dominates in the YS shelf area (Hsueh, 2000; Tomczak \& Godfrey, 2001).

In the ECS shelf region's summer (Fig. 2A), the Kuroshio subsurface water gradually upwells northwestward from east of Taiwan, and finally reaches $30.5^{\circ} \mathrm{N}$ off the Changjiang estuary along $\sim 60 \mathrm{~m}$ isobaths, forming the Nearshore Kuroshio Branch Current (Yang et al., 2012; Yang et al., 2011). Meanwhile, the TWC is formed by the mixing of the Taiwan Strait Warm Current and Kuroshio Surface Water (Qi, 2014). In winter (Fig. 2B), the Kuroshio Surface Water shows relatively intense intrusion as part of the Kuroshio Surface Water northwestward reaches continental shelf area across $100 \mathrm{~m}$ isobaths (Zhao \& Liu, 2015). At this point, the TWC is mainly fed from the Kuroshio Current northeast of Taiwan (Qi, 2014).

Peer) reviewing PDF | (2019:12:44305:2:0:NEW 21 Aug 2020) 
60 In the YS shelf region's summer (Fig. 2A), the Yellow Sea Cold Water Mass, characterized by

61 low temperature, occupies the central low-lying area mostly below the $50 \mathrm{~m}$ isobaths while the

62 Yellow Sea Warm Current shows little influence (Guan, 1963). In winter (Fig. 2B), the impact of

63 the Yellow Sea Warm Current on shelf region is enhanced, while the Yellow Sea Cold Water

64 Mass disappears (Weng et al., 1988). The continuous water circulation in the YS is mainly

65 comprised of the Yellow Sea Warm Current and the China Coastal Current (UNEP, 2005).

66 The radiolarian assemblages in surface sediments have been investigated in the ECS whereas

67 there are few reports in the YS. These reports cover the ECS including the Okinawa Trough

68 (Chang et al., 2003; Cheng \& Ju, 1998; Wang \& Chen, 1996) and continental shelf region

69

70

71

72

73

74

75

76

77

78

79

80

81

82

83

84

85

86

87

88

89

90

91

92

93

94

95

96

97

98

99 extensively (Chen \& Wang, 1982; Tan \& Chen, 1999; Tan \& Su, 1982). They summarize the distribution patterns of the dominant species and the environmental conditions that affect the composition of radiolarian fauna in the ECS in their excellent taxonomic works. On the basis of these valuable works, we rigorously investigate the relationships between radiolarians and environmental variables. In addition, to which the ECS and YS are influenced by the Kuroshio Current and its derivative branch are specially focused in this study. The radiolarian data collected from 59 surface sediment samples are associated with environmental variables of the upper water to explore the principal variables explaining radiolarian species composition. The influences of the Kuroshio Current and its derivative branch on radiolarian assemblages in the study area are also considerably discussed.

\section{Materials \& Methods}

\section{Sample collection and treatment}

The surface sediments were collected at 59 sites (Fig. 3A) in the Yellow Sea and East China Sea using a box corer. The sediment samples in the study area were divided into four groups geographically and were labeled the Yellow Sea region (YSR) samples, the ECS north region (ECSNR) samples, the ECS middle region (ECSMR) samples, and the ECS south region (ECSSR) samples. The samples were prepared using the method described by Chen et al. (2008). $30 \%$ hydrogen peroxide and $10 \%$ hydrochloric acid were added to each dry sample to remove organic component and the calcium tests, respectively. Then the treated sample was sieved with a $50 \mu \mathrm{m}$ sieve and dried in an oven. After flotation in carbon tetrachloride, the cleaned residue was sealed with Canada balsam for radiolarian identification and quantification under a light microscope with a magnification of $200 \mathrm{X}$ or $400 \mathrm{X}$. To reduce counting uncertainty, Dictyocoryne profunda Ehrenberg, Dictyocoryne truncatum (Ehrenberg), Dictyocoryne bandaicum (Harting) were combined as Dictyocoryne group. Photographs of some radiolarians encountered in this study are exhibited in Figure 4.

\section{Environmental data}

Grain size analysis of the surface sediments was conducted with a Laser Diffraction Particle Size Analyzer (Cilas 1190, CILAS, Orleans, Loiret, France). The data were used to categorise grain size classes as clay $(1-4 \mu \mathrm{m})$, silt $(4-63 \mu \mathrm{m})$ and sand $(63-500 \mu \mathrm{m})$, and to determine different sediment types according to the Folk classification (Folk, Andrews \& Lewis, 1970). In addition, the mean grain size was calculated for each site. 
100 The values of annual temperature (SST), salinity (SSS), oxygen, phosphate, nitrate, and silicate 101 of sea surface with a $0.5^{\circ}$ resolution for the period of 1930 to 2009 were derived from the 102 CARS2009 dataset (Ridgway, Dunn \& Wilkin, 2002). The sea surface chlorophyll- $a$ and 103 particulate organic carbon with a $9 \mathrm{~km}$ resolution for the period of 1997 to 2010 were obtained 104 from https://oceancolor.gsfc.nasa.gov/l3/. The values of the environmental variables mentioned 105 above for each surface sediment site were estimated by linear interpolation. These values, 106 together with depth, are shown in Supplementary material Table 1.

\section{Statistical processing}

108

109

110

111

112

113

114

115

116

117

118

119

120

121

122

123

124

125

126

127

128

129

130

131

132

133

134

135

136

137

138

139

The minimum number of specimens counted in each sample is customarily 300 . However, low radiolarian concentrations are frequent in the shelf type sediments comprised mainly of terrigenous sources (Chen et al., 2008). Given small sediment samples, it was difficult to find 300 tests in some sites. According to Fatela \& Taborda (2002), counting 100 tests allows less than $5 \%$ probability of losing those species with a proportion of $3 \%$. Balanced between the insufficient samples and the accuracy of the statistical analysis, the threshold number of radiolarians was adjusted to 100 (Fatela \& Taborda, 2002; Rogers, 2016). Based on this threshold, 24 samples (Fig. 3B) were retained for detailed statistical analysis. Seven of 24 samples had less than 300 tests, containing six ECSNR samples and one ECSSR sample. The proportion of each dominant species in the ECSNR group was higher than 3\%, guaranteeing a reliable interpretation of species proportions.

We calculated the absolute abundance (tests. $\left.(100 \mathrm{~g})^{-1}\right)$ and the diversity indices, including the species number $(S)$, Shannon-Wiener's index $\left(H^{\prime}\left(\log _{\mathrm{e}}\right)\right)$. To ensure a creditable estimate of diversity indices, which may be biased by different counting numbers, the specimens of radiolarians in each sample was randomly subsampled and normalized to the equal size of 100 tests by using rrarefy() function in vegan package in R program. For each site, $S$ and $H^{\prime}$ of sample containing all tests and subsample containing 100 tests were calculated.

Relative abundance (\%) of each radiolarian taxon was also calculated. Then the hierarchical cluster analysis with group-average linking was applied to analyze the variations of radiolarian assemblage among different regions. The percentage data of the relative abundance was transformed by square root for normalize the dataset. Afterwards, triangular resemblance matrix was constructed based on the Bray-Curtis similarity (Clarke \& Warwick, 2001). Analysis of similarity (ANOSIM) was employed to determine the differences among different assemblages. Similarity percentage procedure (SIMPER) analysis was used to identify the species that contributed most to the similarities among radiolarian assemblages.

Detrended correspondence analysis (DCA) was applied to determine the character of the species data. The gradient length of the first DCA axis was $1.773<3$, suggesting that redundancy analysis (RDA, linear ordination method) was more suitable than Canonical correspondence analysis (CCA, unimodal ordination method) (Lepš \& Šmilauer, 2003). RDA was used to evaluate the relationship between environmental variables and radiolarian assemblages identified by SIMPER analysis. The species abundance data was square root transformed before analysis to reduce the effect of extremely high values (Ter Braak \& Smilauer, 2002). Variance inflation 
140 factors (VIF) was calculated to screen the environmental variables with VIF $>5$ (Lomax \& 141 Hahs-Vaughn, 2013). Sand percentage, mean grain size, chlorophyll- $a$, silicate, particulate 142 organic carbon, oxygen, depth, nitrate, and silt percentage were removed from the RDA model 143 step by step, in order to avoid collinearity (Naimi et al., 2014). Finally, four variables, SST, SSS, 144 clay percentage, and phosphate, were employed in the RDA. The significant environmental 145 variables were determined by automatic forward selection with Monte Carlo tests (999

146

147

148

149

150

151

152

153

154

155

156

157

158

159

160

161

162

163

164

165

166

167

168

169

170

171

172

173

174

175

176

177

178

179 permutations). Station DH 8-5 was excluded from the RDA model for lack of environmental data.

Correlation analysis was employed to investigate the relationship between the dominant radiolarian taxa and significant environmental variables.

The diversity indices calculation, cluster analysis, ANOSIM, and SIMPER were performed by PRIMER 6.0. Correlation analysis was performed by SPSS 20. DCA and RDA were conducted by CANOCO 4.5 .

\section{Results}

A total of 137 radiolarian taxa were identified from the surface sediments of study area, including 75 genera, 14 families, and 3 orders The raw radiolarian counting data are in Supplementary material Table 2. Approximately $91.0 \%$ of the species belonged to Spumellaria, accounting for the vast majority of the radiolarian fauna. Nassellaria and Collodaria accounted for $8.4 \%$ and $0.6 \%$, respectively. Pyloniidae definitely dominated in the species composition as they occupied approximately $61 \%$; they are followed by Spongodiscidae $18 \%$, and Coccodiscidae 8\% (Fig. 5A).

Radiolarian abundance in surface sediments varied greatly in study area (Fig. 5B), showing a tendency of ECSMR (2776 tests. $\left.(100 \mathrm{~g})^{-1}\right)>\operatorname{ECSSR}\left(1776\right.$ tests. $\left.(100 \mathrm{~g})^{-1}\right)>\operatorname{ECSNR}(500$ tests. $\left.(100 \mathrm{~g})^{-1}\right)>$ YSR (8 tests. $\left.(100 \mathrm{~g})^{-1}\right)$. The distribution pattern of species number (Fig. 5C) was similar to that of the abundance, exhibiting a trend of ECSMR (38 species) $>$ ECSSR ( 35 species) $>$ ECSNR (16 species) > YSR ( 1 species). The top 9 species taxa, accounting for $79.6 \%$ of the total assemblages in the study area, were as follows: Tetrapyle octacantha group Müller (55.6\%), Didymocyrtis tetrathalamus (Haeckel) (7.5\%), Dictyocoryne group (3.7\%), Spongaster tetras Ehrenberg (2.5\%), Stylodictya multispina Haeckel (2.2\%), Spongodiscus resurgens Ehrenberg (2.2\%), Zygocircus piscicaudatus Popofsky (2.1\%), Phorticium pylonium Haeckel (2.0\%), and Euchitonia furcata Ehrenberg (1.8\%).

\section{The radiolarian assemblages in the YS shelf area}

In general, radiolarians showed a quite low abundance value in the YS, as no tests were found in 15 samples (Fig. 5). For the remaining 10 samples, only 49 tests were originally counted, belonging to 21 species taxa. The radiolarian abundance for 25 samples of the YS ranged from 0 tests. $(100 \mathrm{~g})^{-1}$ to 91 tests. $(100 \mathrm{~g})^{-1}$, and species number ranged from 0 to 12 . Tetrapyle octacantha (17.4\%), Spongodiscus sp. (10.9\%), Didymocyrtis tetrathalamus (9.1\%), Acrosphaera spinosa $(6.1 \%)$, and $P$. pylonium (6.1\%) were the five most abundant species taxa in the YS, constituting $49.7 \%$ of the total assemblages.

Selected stations in the ECS shelf area with radiolarian tests $\geq 100$ 
180

181

182

183

184

185

186

187

188

189

190

191

192

193

194

195

196

197

198

199

200

201

202

203

204

205

206

207

208

209

210

211

212

213

214

215

216

217

218

As can be seen in Table 1, there exists a significant difference in radiolarian abundance between the three regions (ANOVA, $p=0.001$ ). Diversity indices, including $S$ and $H^{\prime}$, displayed an overall ranking of ECSSR $>$ ECSMR $>$ ECSNR both in samples $(S$, Kruskal-Wallis Test, $p=$ $0.000 ; H^{\prime}$, ANOVA, $\left.p=0.000\right)$ and subsamples $\left(S_{\text {sub }}\right.$, ANOVA, $p=0.000 ; H_{\text {sub }}^{\prime}$, ANOVA, $p=$ $0.000)$.

Cluster analysis based on the relative abundance classified all but one site into three regional groups at the $60 \%$ Bray-Curtis similarity level, including the ECSNR group, ECSMR group and ECSSR group (Fig. 6). The significant differences among the three groups were examined by ANOSIM (Global $R=0.769, p=0.001$ ).

The dominant species in each regional group were identified by SIMPER analysis with a cut-off of 50\% (Table 2). Tetrapyle octacantha, Didymocyrtis tetrathalamus, and Spongodiscus resurgens dominated in the ECSNR group, with contribution of $41.70 \%, 9.79 \%$, and $8.89 \%$, respectively. The radiolarian taxa, including T. octacantha, Didymocyrtis tetrathalamus, Dictyocoryne group, Stylodictya multispina, and Spongodiscus resurgens, contributed most to the ECSMR group. The dominant species in the ECSSR group were composed of T. octacantha, Didymocyrtis tetrathalamus, Dictyocoryne group, Spongaster tetras, Z. piscicaudatus, $P$. pylonium, Stylodictya multispina, and E. furcata.

The first two RDA axes explained 39.9\% (RDA1 30.0\%, RDA2 9.9\%) of the species variance, and $86.5 \%$ of the species-environment relation variance (Table $3 \mathrm{~A}$ ). Forward selection with Monte Carlo test (999 Permutation) revealed that SST and SSS were the most significant environmental variables associated with radiolarian composition (Table 3B).

The RDA plot showed a clear distribution pattern of regional samples (Fig. 7A). The ECSNR samples generally occupied the upper left-hand quarter of the ordination, showing a feature of comparatively low SST and low SSS. The ECSMR samples were mostly located in the ordination's centre, suggesting an adaptation to higher values of SST and SSS than the ECSNR samples. The ECSSR samples distributed mainly at lower right-hand quarter, characterized by the highest values of SST and SSS.

The dominant species identified by the SIMPER analysis (Table 2) are displayed in the RDA plot (Fig. 7B). Species taxa, including Spongaster tetras, Dictyocoryne group, Z. piscicaudatus, E. furcata, P. pylonium and Stylodictya multispina, were related to high SST, while showed little relationship with SSS. Didymocyrtis tetrathalamus was positively related to SST and SSS.

Tetrapyle octacantha showed a preference for high SSS. Additionally, Spongodiscus resurgens was adapted to relatively low SST and SSS.

\section{Discussion}

Generally, the number of the radiolarian tests in continental shelf sediments of the ECS and YS is several orders of magnitude lower than that of the adjacent Okinawa trough (Chang et al., 2003; Cheng \& Ju, 1998). Firstly, due to the continental runoff input, the coastal area water is characterised by relatively low temperature and salinity, resulting in few living radiolarians (Chen \& Wang, 1982; Matsuzaki, Itaki \& Kimoto, 2016; Tan \& Su, 1982). Also, the deposition 
219 rate in study area is high at $0.1-0.8 \mathrm{~cm} / \mathrm{yr}$ in the YS, and $0.1-3 \mathrm{~cm} / \mathrm{yr}$ in the ECS (Dong, 2011), 220 which greatly masks the concentration of radiolarian skeleton in sediments (Chang et al., 2003).

221 The radiolarian assemblages in the YS shelf area

222 Based on our results, although radiolarian assemblages varied greatly between the YS and ECS, 223 there are some common species as all of the 21 radiolarian species in the YS can be found in the 224 ECS, that is, no endemic species were observed in the YS. The five most abundant species taxa, 225 except Spongodiscus sp., were reported as typical warm species (Chang et al., 2003; Chen et al., 226 2008; Matsuzaki \& Itaki, 2017), suggesting a warm-water origin of radiolarians in the YS.

227 As a semi-enclosed marginal sea mostly shallower than $80 \mathrm{~m}$, YS is influenced by a continuous 228 circulation, primarily composed of the Yellow Sea Warm Current and China Coastal Current 229 (UNEP, 2005). The mean values of SST and SSS in the YS are $15^{\circ} \mathrm{C}$ and $32 \mathrm{psu}$, respectively 230 (Fig. 1), making it quite difficult for radiolarians to survive and proliferate. For the surface 231

232

233

234

235 sediments in the YS in our study, only a small number of radiolarians were detected at the margin of the YS shelf area, whereas no radiolarians were detected in the 15 sites within the range of the central YS (Fig. 5B). For the planktonic samples in the southern YS, low radiolarian stocks were also reported previously (Tan \& Chen, 1999). Sporadic radiolarians were merely documented in winter, with radiolarian stocks less than 200 tests.m ${ }^{-3}$ (Tan \& Chen, 1999). We

236 thus infer the radiolarians in the YS (Fig. 5) were probably introduced by the Yellow Sea Warm

237 Current, and transported by the China Coastal Current. Whether the absence of radiolarians in

238 the central YS is controlled by the Yellow Sea Cold Water Mass remains unclear and needs

239 future investigation.

240

Selected stations in the ECS shelf area with radiolarian tests $\geq 100$

241 In the ECS, the gradients of SST and SSS are controlled by the interaction of the Kuroshio branch current, TWC and Changjiang Diluted Water (Yang et al., 2012). SST and SSS both

243 show an increase from north to south, corresponding well with the overall distribution of

244 radiolarians (Fig. 1, Fig. 5).

245 As revealed by the RDA, SST was the most significant environmental variable related to the radiolarian composition, followed by SSS (Table 3B). SST is generally regarded as having an extremely important role in controlling the composition and distribution of radiolarians (Boltovskoy \& Correa, 2017; Hernández - Almeida et al., 2017; Ikenoue et al., 2015). According to Matsuzaki, Itaki \& Tada (2019), the species diversity in the northern ECS was higher during interglacial period than during glacial period. For a long time, the relationship between radiolarian assemblages and SST has been used to construct past changes in hydrographic conditions (Matsuzaki \& Itaki, 2017). In this study, SST showed a significant correlation with abundance, species number, and $H^{\prime}$ (Table 4), suggesting that higher SST may often correspond to higher diversity.

255 SSS was also crucial for explaining species-environment correlations in the ECS shelf area. At the offshore Western Australia, salinity is strongly significant in determining radiolarian species distributions (Rogers, 2016). Hernández - Almeida et al. (2017) and Liu et al. (2017a) stated that the composition and distribution pattern of the radiolarian fauna in the western Pacific responds 
259

260

261

262

263

264

265

266

267

268

269

270

271

272

273

274

275

276

277

278

279

280

281

282

283

284

285

286

287

288

289

290

291

292

293

294

295

296

297

298

mainly to SST and SSS. Gupta (2002) found that the relative abundance of Pyloniidae exhibits a positive correlation with salinity. In this study SSS was positively correlated to abundance and species number (Table 4), possibly suggesting a positive influence of SSS on radiolarian diversity.

The radiolarian assemblages of the ECSSR group are influenced by the Kuroshio Current and TWC, with the TWC predominating. The surface water of the TWC is mainly characterised by high temperature $\left(23-29^{\circ} \mathrm{C}\right.$ ) and salinity (33.3-34.2psu) (Weng \& Wang, 1988). Some of the TWC waters are supplemented from the South China Sea (Liu et al., 2017b), where radiolarians show high diversity (Chen et al., 2008; Liu et al., 2017a; Zhang et al., 2009). The dominant species in the ECSSR group include T. octacantha, Didymocyrtis tetrathalamus, Dictyocoryne group, Spongaster tetras, Z. piscicaudatus, P. pylonium, Stylodictya multispina, and E. furcata (Table 2, Fig. 8). These species taxa are reported as typical indicators of the Kuroshio Current (Chang et al., 2003; Gallagher et al., 2015; Liu et al., 2017a; Matsuzaki et al., 2016). The relatively high abundance of these taxa in the study area reflects the influence of the warm Kuroshio and TWC waters. Moreover, moderate percentage $(0.91 \%)$ of Pterocorys campanula Haeckel was detected in the ECSSR group, in contrast with the ECSMR group (0.14\%) and ECSNR group ( $0.06 \%)$. Members of Pterocorys are shallow-water dwellers, as reported by Matsuzaki, Itaki \& Sugisaki (2020). Pterocorys campanula frequently occurs and dominates in the South China Sea, whereas there are no reports of the dominance of $P$. campanula in the sediment samples of the ECS (Chen \& Tan, 1996; Chen et al., 2008; Hu et al., 2015; Liu et al., 2017a). The high abundance of this taxon in the ECSSR group further demonstrates our conclusion that radiolarian assemblages of the ECSSR group are brought by the Kuroshio Current and TWC with the TWC playing the main role.

The ECSMR group was influenced by the Kuroshio Current, TWC, and Changjiang Diluted Water. The dominant species in the ECSMR included T. octacantha, Didymocyrtis tetrathalamus, Dictyocoryne group, Stylodictya multispina and Spongodiscus resurgens (Table 2). The dominant species of the ECSMR group show a great overlap with the ECSSR group, which, in some degree, suggests a similarity between the two groups, as both are influenced by the Kuroshio Current and TWC. On the other hand, the lower percentages of Didymocyrtis tetrathalamus, Dictyocoryne group, and Stylodictya multispina indicate part of the impact of the Changjiang Diluted Water, which is characterized by lower SST (Fig. 8).

Tetrapyle octacantha, Didymocyrtis tetrathalamus, and Spongodiscus resurgens are the dominant species of the ECSNR group, which is primarily impacted by the Changjiang Diluted Water and Kuroshio Current. Compared to the ECSMR and ECSSR group, the ECSNR group occupied higher latitude which means a lower SST, while the large input of Changiiang Diluted Water lowers the SSS (Fig. 1). This combination of lower SST and SSS probably hindered the radiolarian diversity of the ECSNR (Table 1).

The radiolarian assemblages in the shallower sea, i.e., the shelf sea area of the ECS, displayed distinctly different patterns from those in the open ocean. Tetrapyle octacantha occurred in the extraordinarily high proportion of 59\% in the study area (Fig. 8), much higher than ever reported 
299

300

301

302

303

304

305

306

307

308

309

310

311

312

313

314

315

316

317

318

319

320

321

322

323

324

325

326

327

328

329

330

331

332

333

334

335

336

337

338

in adjacent areas with deeper waters (Chang et al., 2003; Cheng \& Ju, 1998; Liu et al., 2017a; Wang \& Chen, 1996). The response of T. octacantha to SSS was unclear, although it showed positive relationship with SSS in the RDA plot (Fig. 7B). Here a special station with the highest Shannon-Wiener's index (3.2 in both original sample and subsample) was noticed, namely the station 3000-1 (Fig. 3), which is located at the Changjiang estuary. In our study, it had the lowest value of salinity (26.6psu) and the lowest percentage of $T$. octacantha (14.8\%). After removing 3000-1, no significant correlation existed between SSS and the relative abundance of $T$. octacantha $(\mathrm{n}=22, r=-0.027, p=0.906)$. Tetrapyle octacantha, as the most abundant taxon in the subtropical area (Boltovskoy, 1989), shows a high resistance to SST variation (Ishitani et al., 2008). This taxon has been reported to be associated with water from the ECS shelf area (Chang et al., 2003; Itaki, Kimoto \& Hasegawa, 2010). Welling \& Pisias (1998) concluded that $T$. octacantha dominated during the cold tongue period in the central equatorial Pacific. In the northwest Pacific, there seems to be a threshold value of $\sim 16^{\circ} \mathrm{C}$ that only sporadic tests of $T$. octacantha are found with the temperature lower than $16{ }^{\circ} \mathrm{C}(<6$ tests, see Data Set S1 and Table 1 in Matsuzaki \& Itaki, 2017). In our study, there are very few tests of T. octacantha at the temperature below $16^{\circ} \mathrm{C}$ (Supplementary material Tables 1 and 2), tending to confirm the former

research. We thus infer that $T$. octacantha is possibly more resistant to locally severe temperature and, so, reaches comparatively high abundance in the ECS shelf area. Therefore, T. octacantha could serve as an indicator that depicts the degree of mixture between the colder shelf water and warm Kuroshio water. Spongodiscus resurgens, with an upper sub-surface maximum, was generally considered to be cold water species (Suzuki \& Not, 2015) and related to productive nutrient-rich water (Itaki, Minoshima \& Kawahata, 2009; Matsuzaki \& Itaki, 2017). The ECSNR group was primarily controlled by the colder Changjiang Diluted Water, and thus had the highest percentage of $T$. octacantha and Spongodiscus resurgens among three regions.

\section{Conclusions}

We analyzed radiolarian assemblages collected from the YS and ECS shelf area, where the Kuroshio Current and its derivative branches, including the TWC and Yellow Sea Warm Current, exerts great effect.

(1) The radiolarian abundance in the YS was quite low, and no radiolarians were detected in 15 of 25 YS sites.

(2) The radiolarian abundance and diversity in the ECS, which is controlled by the Kuroshio warm water, was much higher. Based on the cluster analysis, the radiolarian assemblages in the ECS could be divided into three regional groups, namely the ECSNR group, ECSMR group and ECSSR group.

a. The ECSNR group was chiefly impacted by the Changjiang Diluted Water and Kuroshio Current, with dominant species of T. octacantha, Didymocyrtis tetrathalamus, and Spongodiscus resurgens.

b. The ECSMR group was controlled by the Kuroshio Current, TWC and Changjiang Diluted Water. Species contributed most to this group included T. octacantha, Didymocyrtis tetrathalamus, Dictyocoryne group, Stylodictya multispina, and Spongodiscus resurgens. 
c. The ECSSR group was affected by the Kuroshio Current and TWC, in which the TWC occupies major status. The dominant species in this group were composed of T. octacantha, Didymocyrtis tetrathalamus, Dictyocoryne group, Spongaster tetras, Z. piscicaudatus, $P$. pylonium, Stylodictya multispina, and Euchitonia furcata.

(3) The RDA results indicated that SST and SSS were main environmental variables that influenced the radiolarian composition in the ECS shelf.

\section{Acknowledgements}

We are grateful to laboratory members for collecting sediment samples. We thank Dr. Lanlan Zhang for advising on this research. We also appreciate Dr. Kenji M. Matsuzaki, Dr. John Rogers, and the editor for their valuable comments on the manuscript.

\section{References}

Abelmann A, Nimmergut A. 2005. Radiolarians in the Sea of Okhotsk and their ecological implication for paleoenvironmental reconstructions. Deep-Sea Research II 52:2302-2331. https://doi.org/10.1016/j.dsr2.2005.07.009

Anderson OR. 1983. Radiolaria. New York: Springer Science \& Business Media.

Boltovskoy D. 1989. Radiolarian record of the last 40,000 years in the western equatorial Pacific. Oceanologica Acta 12:79-86.

Boltovskoy D, Correa N. 2017. Planktonic equatorial diversity troughs: fact or artifact? Latitudinal diversity gradients in Radiolaria. Ecology 98:112-124. https://doi.org/10.1002/ecy.1623

Chang FM, Zhuang LH, Li TG, Yan J, Cao QY, Cang SX. 2003. Radiolarian fauna in surface sediments of the northeastern East China Sea. Marine Micropaleontology 48:169-204. https://doi.org/10.1016/s0377-8398(03)00016-1

Chen MH, Tan ZY. 1996. Radiolaria from Surface Sediments of the Central and Northern South China Sea. Beijing: Science Press.

Chen MH, Zhang LL, Zhang L, Xiang R, Lu J. 2008. Preservation of radiolarian diversity and abundance in surface sediments of the South China Sea and its environmental implication. Journal of China University of Geosciences 19:217-229. https://doi.org/10.1016/s1002-0705(08)60041-2

Chen W, Wang B. 1982. A preliminary study on the Radiolaria from surface sediments of the East China Sea (in Chinese with English abstract). Marine Geological Research 2:59-69.

Cheng Z, Ju X. 1998. Radiolaria from the Surface Sediments in the Middle Okinawa Trough (in Chinese with English abstract). Oceanologia et Limnologia Sinica 29:662-665.

Clarke K, Warwick R. 2001. Changes in Marine Communities: An Approach to Statistical Analysis and Interpretation. 2nd ed. Plymouth: PRIMER-E Ltd.

Dong A. 2011. Source, Sink and its Environmental Record of Sediments in Yellow Sea and East China Sea. Ocean University of China.

Fatela F, Taborda R. 2002. Confidence limits of species proportions in microfossil assemblages. Marine Micropaleontology 45:169-174. https://doi.org/10.1016/s0377-8398(02)00021-x 
378 Folk RL, Andrews P, Lewis DW. 1970. Detrital sedimentary rock classification and

379

380

381

382

383

384

385

386

387

388

389

390

391

392

393

394

395

396

397

398

399

400

401

402

403

404

405

406

407

408

409

410

411

412

413

414

415

416 nomenclature for use in New Zealand. New Zealand Journal of Geology \& Geophysics 13:937-968. http://dx.doi.org/10.1080/00288306.1970.10418211

Gallagher SJ, Kitamura A, Iryu Y, Itaki T, Koizumi I, Hoiles PW. 2015. The Pliocene to recent history of the Kuroshio and Tsushima Currents: a multi-proxy approach. Progress in Earth and Planetary Science 2. https://doi.org/10.1186/s40645-015-0045-6

Guan B. 1963. A preliminary study of the temperature variations and the characteristics of the circulation of the cold water mass of the Yellow Sea (in Chinese with English abstract). Oceanologia et Limnologia Sinica 5:255-284.

Gupta SM. 2002. Pyloniid stratigraphy-a new tool to date tropical radiolarian ooze from the central tropical Indian Ocean. Marine Geology 184:85-93. https://doi.org/10.1016/S00253227(01)00276-6

Hernández-Almeida I, Cortese G, Yu PS, Chen MT, Kucera M. 2017. Environmental determinants of radiolarian assemblages in the western Pacific since the last deglaciation. Paleoceanography 32:830-847. https://doi.org/10.1002/2017PA003159

Hsueh Y. 2000. The Kuroshio in the East China Sea. Journal of Marine Systems 24:131-139. https://doi.org/10.1016/S0924-7963(99)00083-4

Hu W, Zhang L, Chen M, Zeng L, Zhou W, Xiang R, Zhang Q, Liu S. 2015. Distribution of living radiolarians in spring in the South China Sea and its responses to environmental factors. Science China Earth Sciences 58:270-285. https://doi.org/10.1007/s11430-0144950-0

Ikenoue T, Bjørklund K, Kruglikova S, Onodera J, Kimoto K, Harada N. 2015. Flux variations and vertical distributions of siliceous Rhizaria (Radiolaria and Phaeodaria) in the western Arctic Ocean: indices of environmental changes. Biogeosciences 12. https://doi.org/10.5194/bg-12-2019-2015

Ishitani Y, Takahashi K, Okazaki Y, Tanaka S. 2008. Vertical and geographic distribution of selected radiolarian species in the North Pacific. Micropaleontology 54:27-39.

Itaki T, Kimoto K, Hasegawa S. 2010. Polycystine radiolarians in the Tsushima Strait in autumn of 2006. Paleontological Research 14:19-32. https://doi.org/10.2517/1342-8144-14.1.019

Itaki T, Minoshima K, Kawahata H. 2009. Radiolarian flux at an IMAGES site at the western margin of the subarctic Pacific and its seasonal relationship to the Oyashio Cold and Tsugaru Warm currents. Marine Geology 255:131-148. https://doi.org/10.1016/j.margeo.2008.07.006

Jun P. 2014. The Delimitation of the Continental Shelf beyond 200 Nautical Miles in the East China Sea. China Oceans Law Review:124.

Lazarus D, Suzuki N, Caulet JP, Nigrini C, Goll I, Goll R, Dolven JK, Diver P, Sanfilippo A. 2015. An evaluated list of Cenozic-Recent radiolarian species names (Polycystinea), based on those used in the DSDP, ODP and IODP deep-sea drilling programs. Zootaxa 3999:301-333. 10.11646/zootaxa.3999.3.1 
417 Lepš J, Šmilauer P. 2003. Multivariate Analysis of Ecological Data Using CANOCO.

418 Cambridge: Cambridge university press.

419 Liu L, Zhang Q, Chen M, Zhang L, Xiang R. 2017a. Radiolarian biogeography in surface

$420 \quad$ sediments of the Northwest Pacific marginal seas. Science China Earth Sciences 60:517-

$421 \quad 530$. https://doi.org/10.1007/s11430-016-5179-4

422 Liu W, Song J, Yuan H, Li N, Li X, Duan L. 2017b. Dissolved barium as a tracer of Kuroshio

423

424

425

426

427

428

429

430

431

432

433

434

435

436

437

438

439

440

441

442

443

444

445

446

447

448

449

450

451

452

453

454

455

456 incursion in the Kuroshio region east of Taiwan Island and the adjacent East China Sea (in Chinese with English abstract). Science China Earth Sciences:160-171.

Lomax RG, Hahs-Vaughn DL. 2013. An introduction to statistical concepts: Routledge.

Lombari G, Boden G. 1985. Modern radiolarians global distributions. Cushman Foundation for Foraminiferal Research, Special Publication 16:1-125.

Matsuzaki KM, Itaki T. 2017. New northwest Pacific radiolarian data as a tool to estimate past sea surface and intermediate water temperatures. Paleoceanography 32:218-245. http://dx.doi.org/10.1002/2017PA003087

Matsuzaki KM, Itaki T, Kimoto K. 2016. Vertical distribution of polycystine radiolarians in the northern East China Sea. Marine Micropaleontology 125:66-84. https://doi.org/10.1016/j.marmicro.2016.03.004

Matsuzaki KM, Itaki T, Sugisaki S. 2020. Polycystine radiolarians vertical distribution in the subtropical Northwest Pacific during Spring 2015 (KS15-4). Paleontological Research 24: 113-133. http://dx.doi.org/10.2517/2019PR019

Matsuzaki KM, Itaki T, Tada R. 2019. Paleoceanographic changes in the Northern East China Sea during the last $400 \mathrm{kyr}$ as inferred from radiolarian assemblages (IODP Site U1429). Progress in Earth and Planetary Science 6:1-21. http://dx.doi.org/10.1186/s40645-0190256-3

Naimi B, Hamm NA, Groen TA, Skidmore AK, Toxopeus AG. 2014. Where is positional uncertainty a problem for species distribution modelling? Ecography 37:191-203.

Pi Z. 2016. The evolution of the Yellow Sea Warm Current under the background of East Asian Monsoon since mid Holoence (in Chinese with English abstract). Institute of Oceanology, Chinese Academy of Sciences.

Qi J. 2014. The study on the Water Masses, Kuroshio and Water Exchange in the East China Sea (in Chinese with English abstract). Institute of Oceanology, Chinese Academy of Sciences.

Qiu B. 2001. Kuroshio and Oyashio currents. Ocean Currents: A Derivative of the Encyclopedia of Ocean Sciences:61-72. https://doi.org/10.1006/rwos.2001.0350

Ridgway K, Dunn J, Wilkin J. 2002. Ocean interpolation by four-dimensional weighted least squares-Application to the waters around Australasia. Journal of atmospheric and oceanic technology 19:1357-1375. https://doi.org/10.1175/15200426(2002)019<1357:oibfdw>2.0.co;2

Rogers J. 2016. Monsoonal and other climatic influences on radiolarian species abundance over the last $35 \mathrm{ka}$, as recorded in core FR10/95-GC17, off North West Cape (Western 
457

458

459

460

461

462

463

464

465

466

467

468

469

470

471

472

473

474

475

476

477

478

479

480

481

482

483

484

485

486

487

488

489

490

491

492

493

494

495

Australia). Revue de Micropaleontologie 59:275-293.

https://doi.org/10.1016/j.revmic.2016.05.003

Suzuki N. 2016. The statistic information on radiolarian studies based on PaleoTax for Windows, a synonym database (in Japanese with English abstract). Fossils 99:15-31.

Suzuki N, Not F. 2015. Biology and Ecology of Radiolaria. Japan: Springer Japan.

Takahashi K. 1981. Vertical Flux, Ecology and Dissolution of Radiolaria in Tropical Oceans: Implications for the Silica Cycle. Massachusetts Institute of Technology and Woods Hole Oceanographic Institution.

Tan Z, Chen M. 1999. Offshore Radiolaria from China (in Chinese with English abstract). Bejing: Science Press.

Tan Z, Su X. 1982. Studies on the Radiolaria in sediments of the East China Sea (continental shelf) (in Chinese with English abstract). Studia Marina Sinica 19:129-216.

Ter Braak CJ, Smilauer P. 2002. CANOCO reference manual and CanoDraw for Windows user's guide: software for canonical community ordination (version 4.5). Microcomputer Power.

Tomczak M, Godfrey JS. 2001. Regional Oceanography: An Introduction (Version 1.0). Oxford: Pergamon Press.

UNEP. 2005. In: Teng, S.K., Yu, H., Tang, Y., Tang, L., Choi, C.Y., Kang, D., Liu, H., Chun, Y., Juliano, R.O., Rautalahti-Miettinen, E., Daler, D. (Eds.), Yellow Sea. GIWA Regional Assessment 34. University of Kalmar, Kalmar, Sweden.

Wang JB. 2012. Study on the Ecology and Taxonomy of polycystine Radiolaria from three aeras of the South China Sea (in Chinese with English abstract). Institute of Oceanology, Chinese Academy of Sciences.

Wang R, Chen R. 1996. Preliminary study on the Radiolaria from the surface sediments in southern Okinawa Trough (in Chinese with English abstract). Journal of Tongji University:670-676.

Welling LA, Pisias NG. 1998. Radiolarian fluxes, stocks, and population residence times in surface waters of the central equatorial Pacific. Deep-Sea Research Part I: Oceanographic Research Papers 45:639-671.

Weng X, Wang C. 1988. On the Taiwan Warm Current Water. Chinese Journal of Oceanology \& Limnology 6:320-329.

Weng X, Zhang Y, Wang C, Zhang Q. 1988. The variational characteristics of the Huanghai Sea (Yellow Sea) cold water mass (in Chinese with English abstract). Oceanologia et Limnologia Sinica 19:368-379.

Xu D, Li X, Zhu J, Qi Y. 2011. Evaluation of an ocean data assimilation system for Chinese marginal seas with a focus on the South China Sea. Chinese Journal of Oceanology and Limnology 29:414-426. https://doi.org/10.1007/s00343-011-0044-4

Yang D, Yin B, Liu Z, Bai T, Qi J, Chen H. 2012. Numerical study on the pattern and origins of Kuroshio branches in the bottom water of southern East China Sea in summer. Journal of Geophysical Research: Oceans 117:1-16. https://doi.org/10.1029/2011jc007528 
496 Yang D, Yin B, Liu Z, Feng X. 2011. Numerical study of the ocean circulation on the East China 497 Sea shelf and a Kuroshio bottom branch northeast of Taiwan in summer. Journal of 498 Geophysical Research: Oceans 116. https://doi.org/10.1029/2010jc006777

499 Yasudomi Y, Motoyama I, Oba T, Anma R. 2014. Environmental fluctuations in the 500 northwestern Pacific Ocean during the last interglacial period: evidence from radiolarian $501 \quad$ assemblages. Marine Micropaleontology 108:1-12.

$502 \quad$ https://doi.org/10.1016/j.marmicro.2014.02.001

503 Zhang L, Chen M, Xiang R, Zhang J, Liu C, Huang L, Lu J. 2009. Distribution of polycystine 504 radiolarians in the northern South China Sea in September 2005. Marine

505 Micropaleontology 70:20-38. https://doi.org/10.1016/j.marmicro.2008.10.002

506 Zhao RX, Liu ZL. 2015. The seasonal variability of the Kuroshio surface water intrusion onto 507 the East China Sea continental shelf derived from Argos drifter data (in Chinese with $508 \quad$ English abstract). Marine Sciences 39:118-123. 
Figure 1

The mean annual sea surface temperature (SST, A) and sea surface salinity (SSS, B) in the shelf area of the ECS and YS.

Solid line indicates the boundary between the ECS and YS.

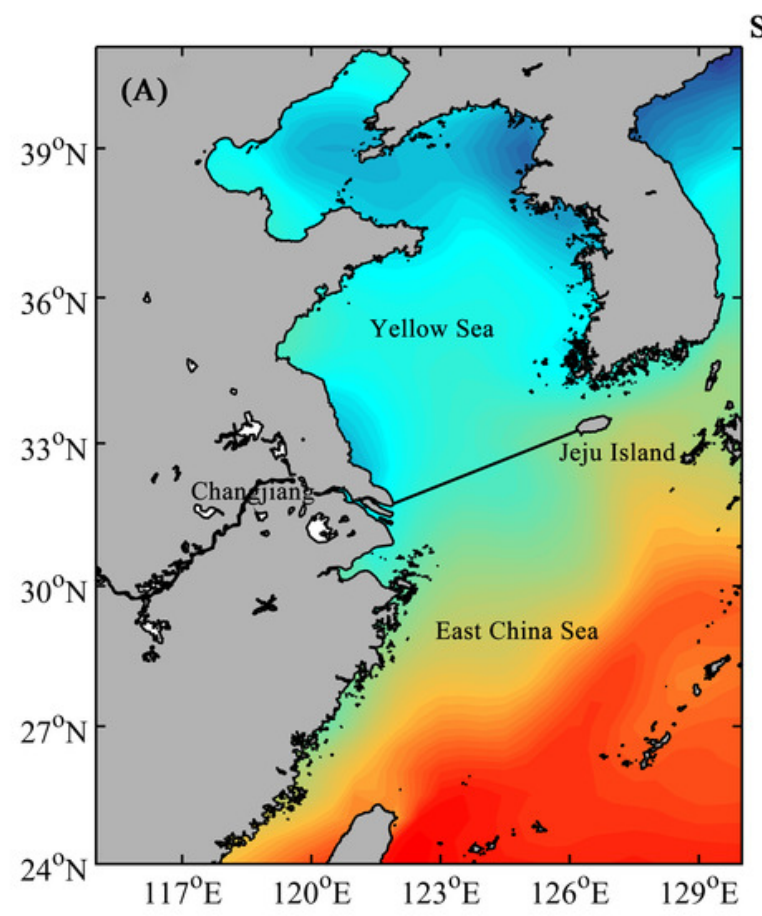

$\operatorname{SST}\left({ }^{\circ} \mathrm{C}\right)$

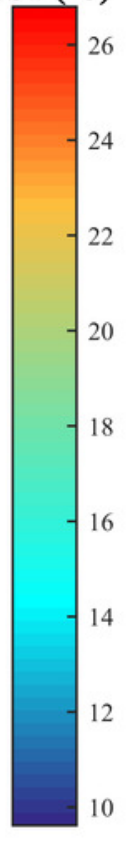

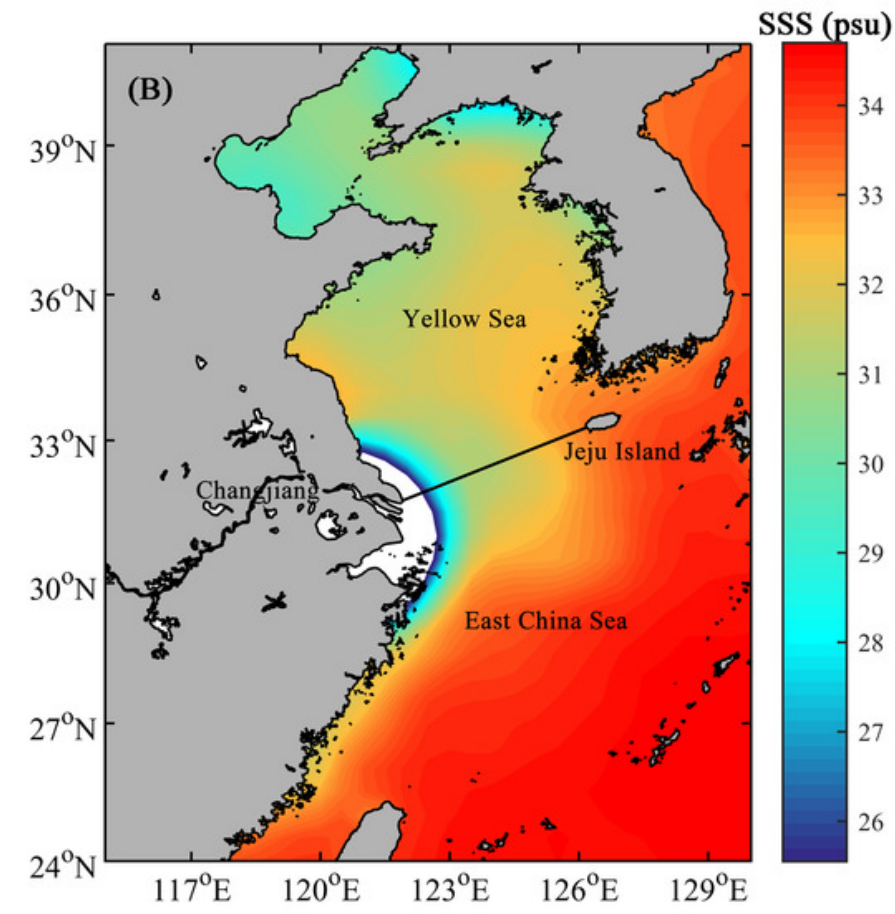




\section{Figure 2}

The circulation system of the study area in summer $(A)$ and winter (B) (redrawn after Yang et al. (2012) and Pi (2016)).

Abbreviations: KBC - Kuroshio Branch Current, OKBC - Offshore Kuroshio Branch Current, NKBC - Nearshore Kuroshio Branch Current, KSW - Kuroshio Surface Water, TWC - Taiwan Warm Current, CCC - China Coastal Current, CDW - Changjiang Diluted Water, YSCWM Yellow Sea Cold Water Mass, YSWC - Yellow Sea Warm Current, TC - Tsushima Current.
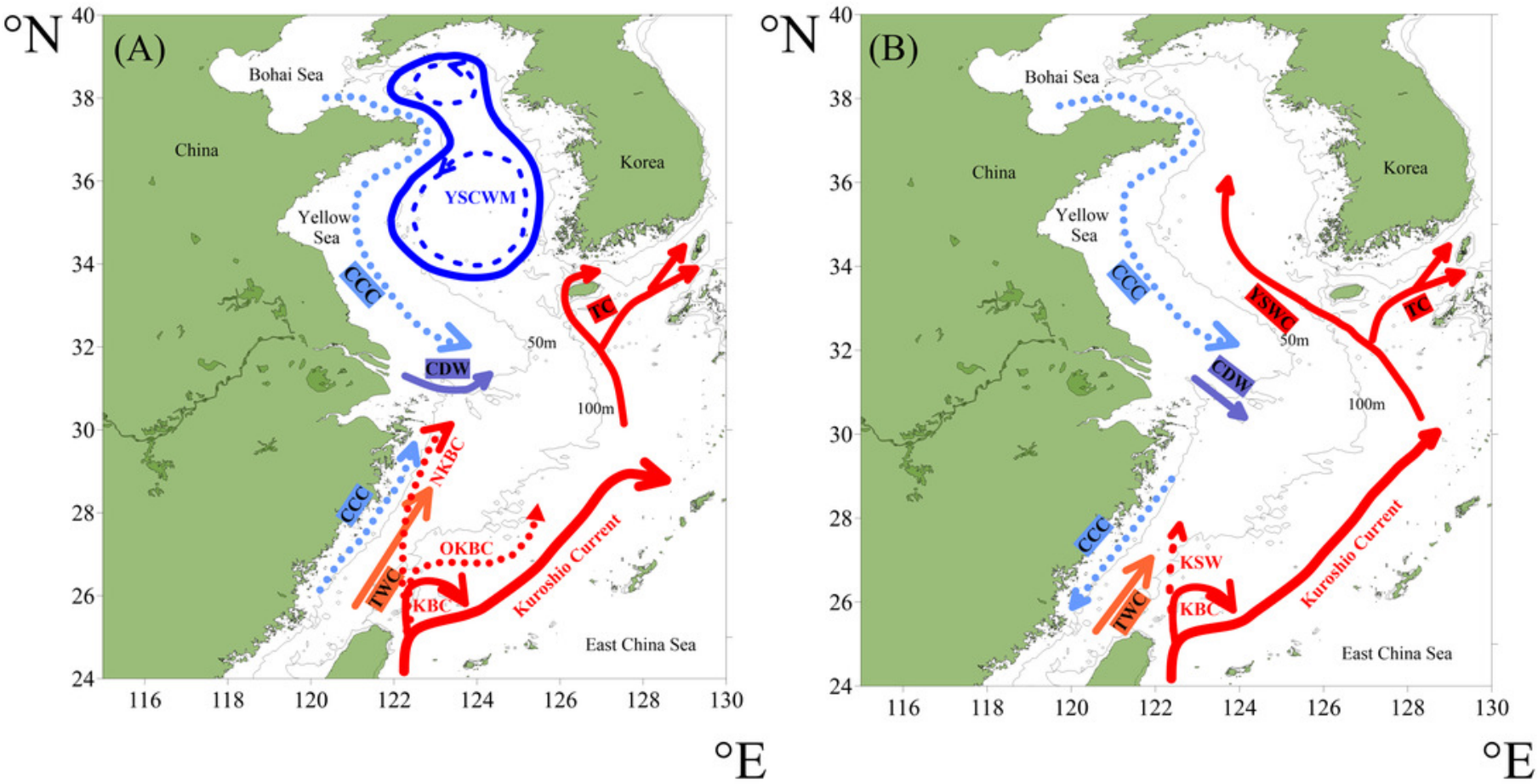


\section{Figure 3}

The location of the total surface sediment samples in the ECS and YS shelf area (A), and simplified 24 samples with a threshold of 100 tests (B).

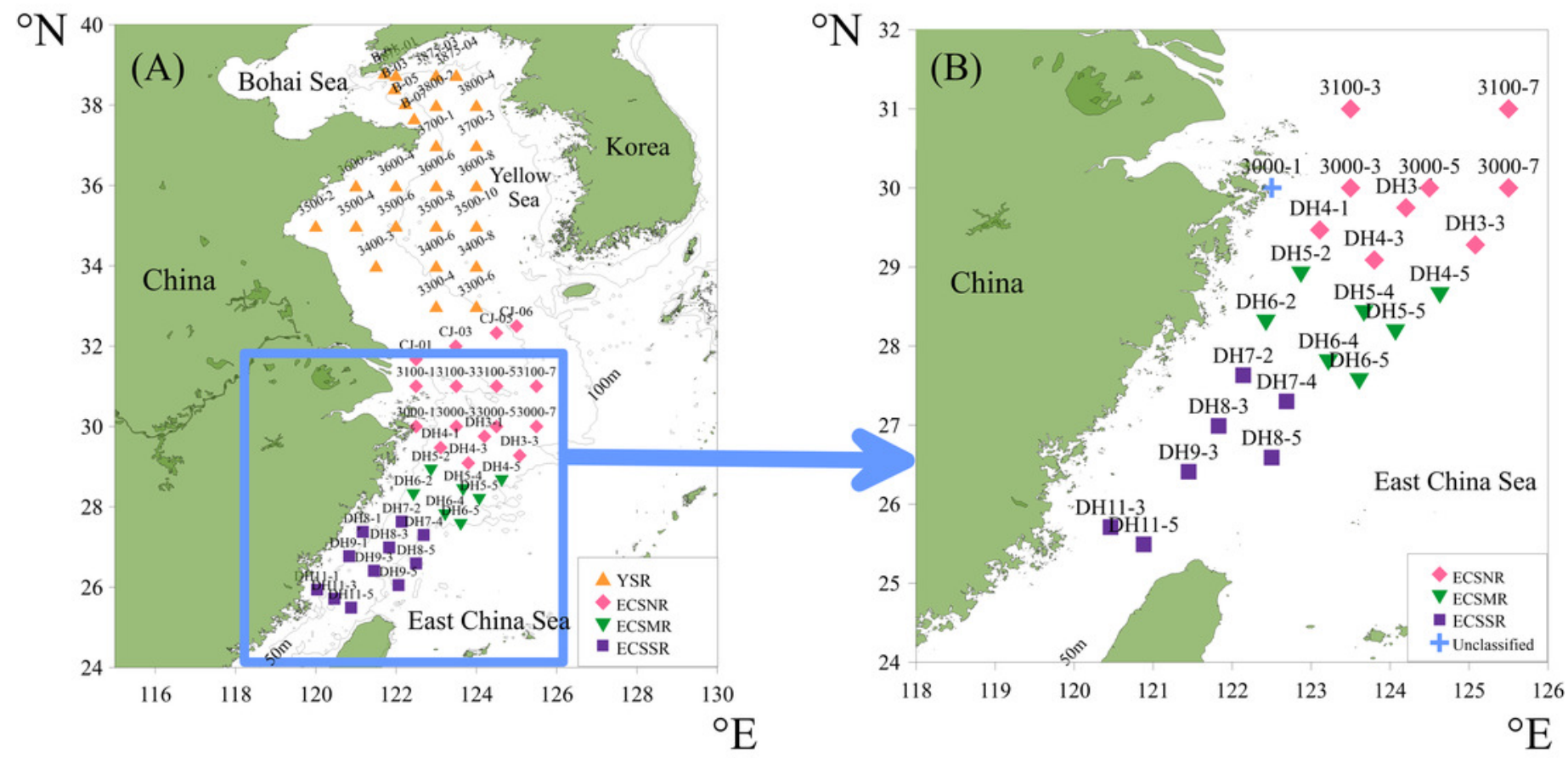




\section{Figure 4}

Some radiolarians encountered in this study.

A. Dictyocoryne group; B. Didymocyrtis tetrathalamus (Haeckel); C. Phorticium pylonium Haeckel; D. Spongaster tetras Ehrenberg; E. Spongodiscus resurgens Ehrenberg; F. Stylodictya multispina Haeckel; G-H, Tetrapyle octacantha group Müller; I-J, Zygocircus piscicaudatus Popofsky; K. Flustrella polygonia (Popofsky); L. Sethodiscus macrococcus Haeckel; M. Hexacontium pachydermum Jorgensen; N, Amphibrachium sponguroides Haeckel; O, Collosphaera sp.; P-Q, Pseudocubus obeliscus Haeckel; R, Acanthocorys castanoides Tan \& Tchang; S, Peromelissa spinosissima Tan \& Tchang; T, Peridium sp.; U. Cycladophora bicornis (Popofsky); V. Helotholus histricosa Jorgensen; W. Phormospyris stabilis stabilis (Goll); X. Lithopera bacca Ehrenberg; Y. Lipmanella dictyoceras (Haeckel). Scale bar $=50 \mu \mathrm{m}$. 

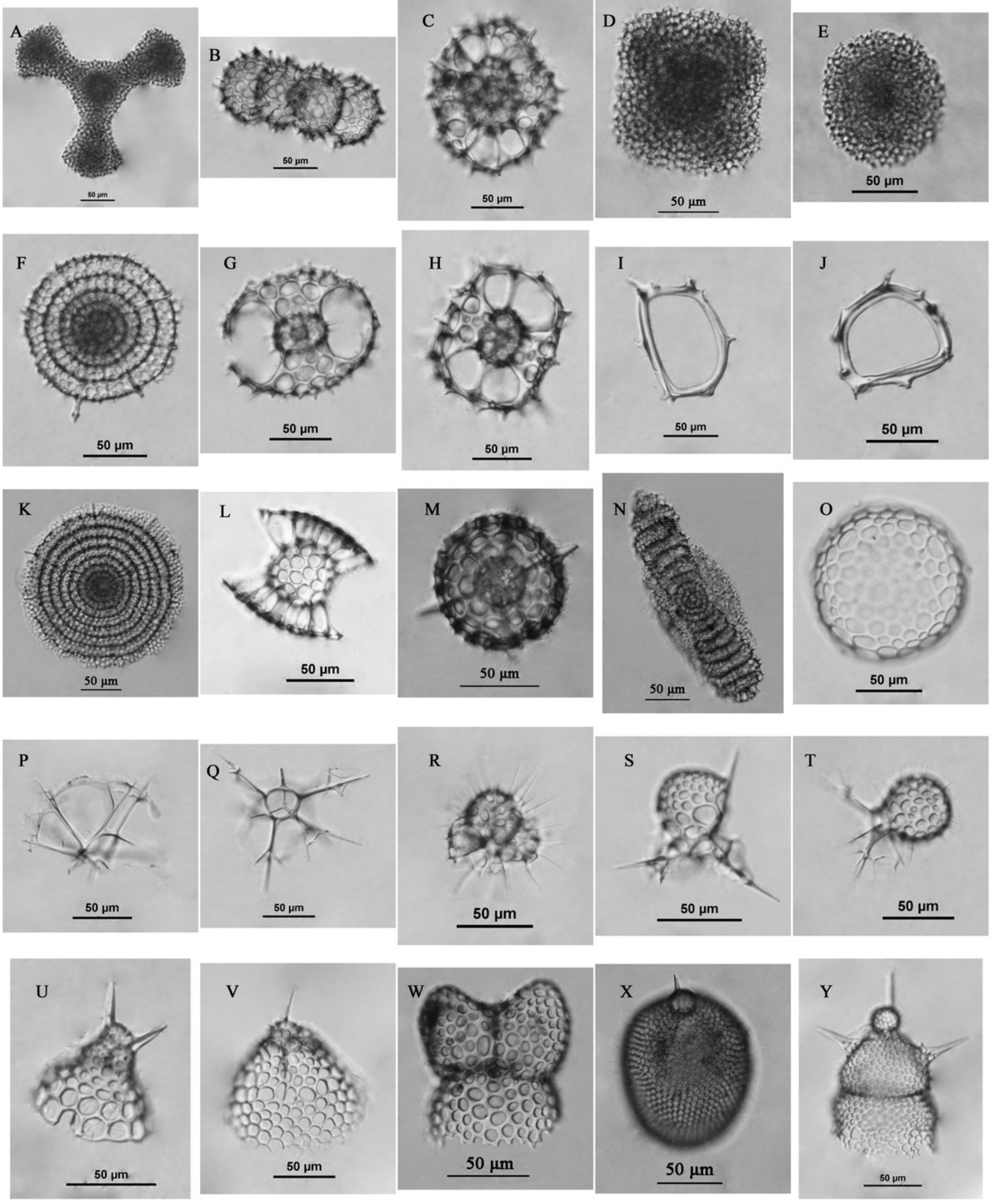


\section{Figure 5}

Total relative abundance (A), absolute abundance (B), and species number (C) of the radiolarians in the surface sediments.
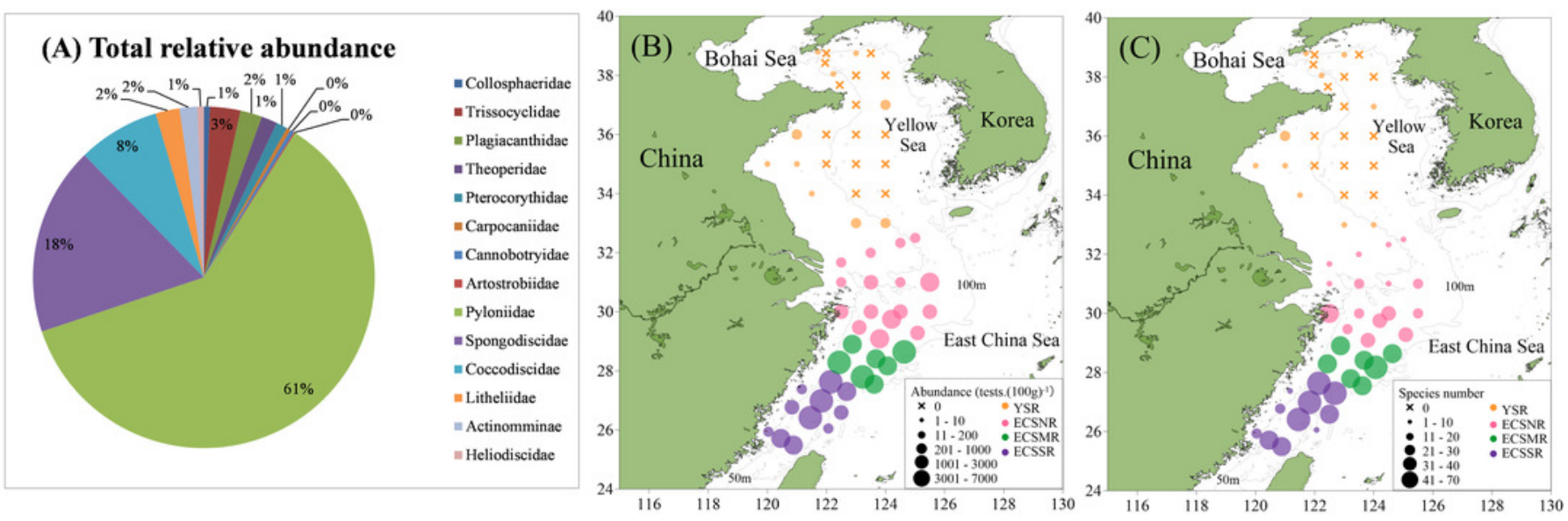
Figure 6

Cluster analysis of radiolarian assemblages in the ECSNR, ECSMR and ECSSR.

The dotted line represents $60 \%$ similarity level.

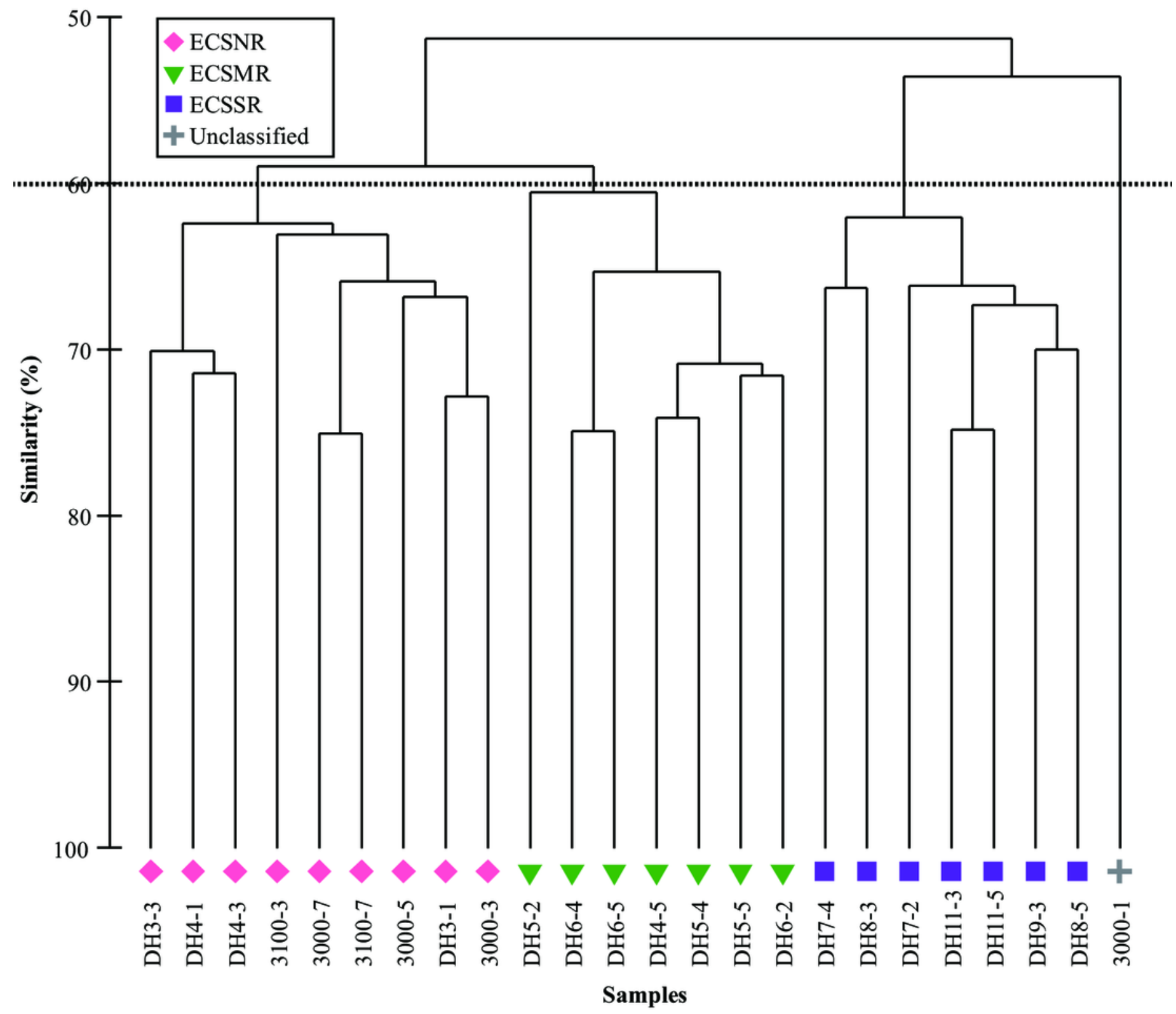


Figure 7

The redundancy analysis (RDA) ordination: (A) samples, (B) species.

Species codes: DicGro - Dictyocoryne group, DidTet - Didymocyrtis tetrathalamus, EucFur -Euchitonia furcata, PhoPyl - Phorticium pylonium, SpoTet - Spongaster tetras, SpoRes Spongodiscus resurgens, StyMul - Stylodictya multispina, TetOct - Tetrapyle octacantha, ZygPis - Zygocircus piscicaudatus (in alphabetical order).
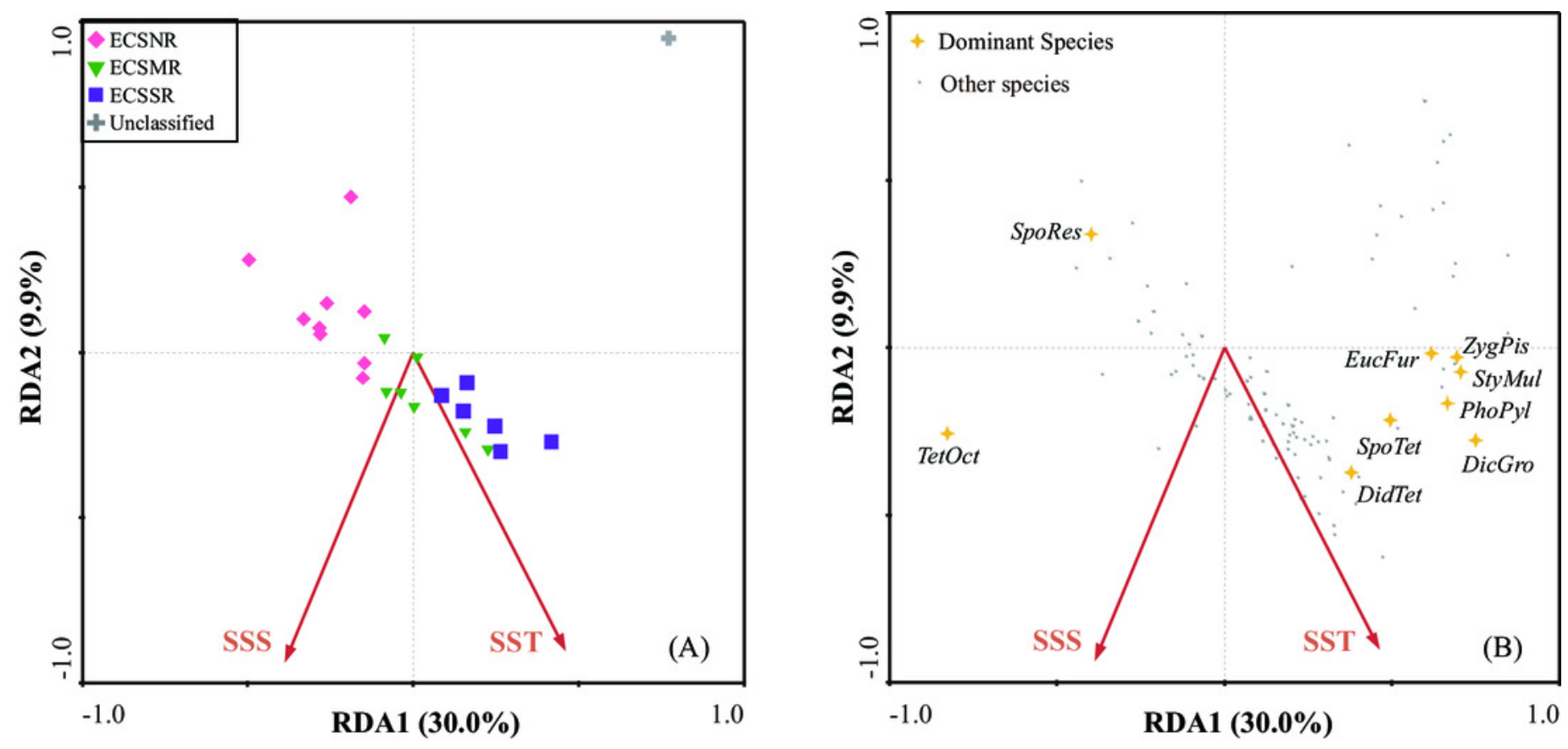
Figure 8

Distribution of the dominant radiolarian species, SST, and SSS in the ECSNR, ECSMR, ECSSR.

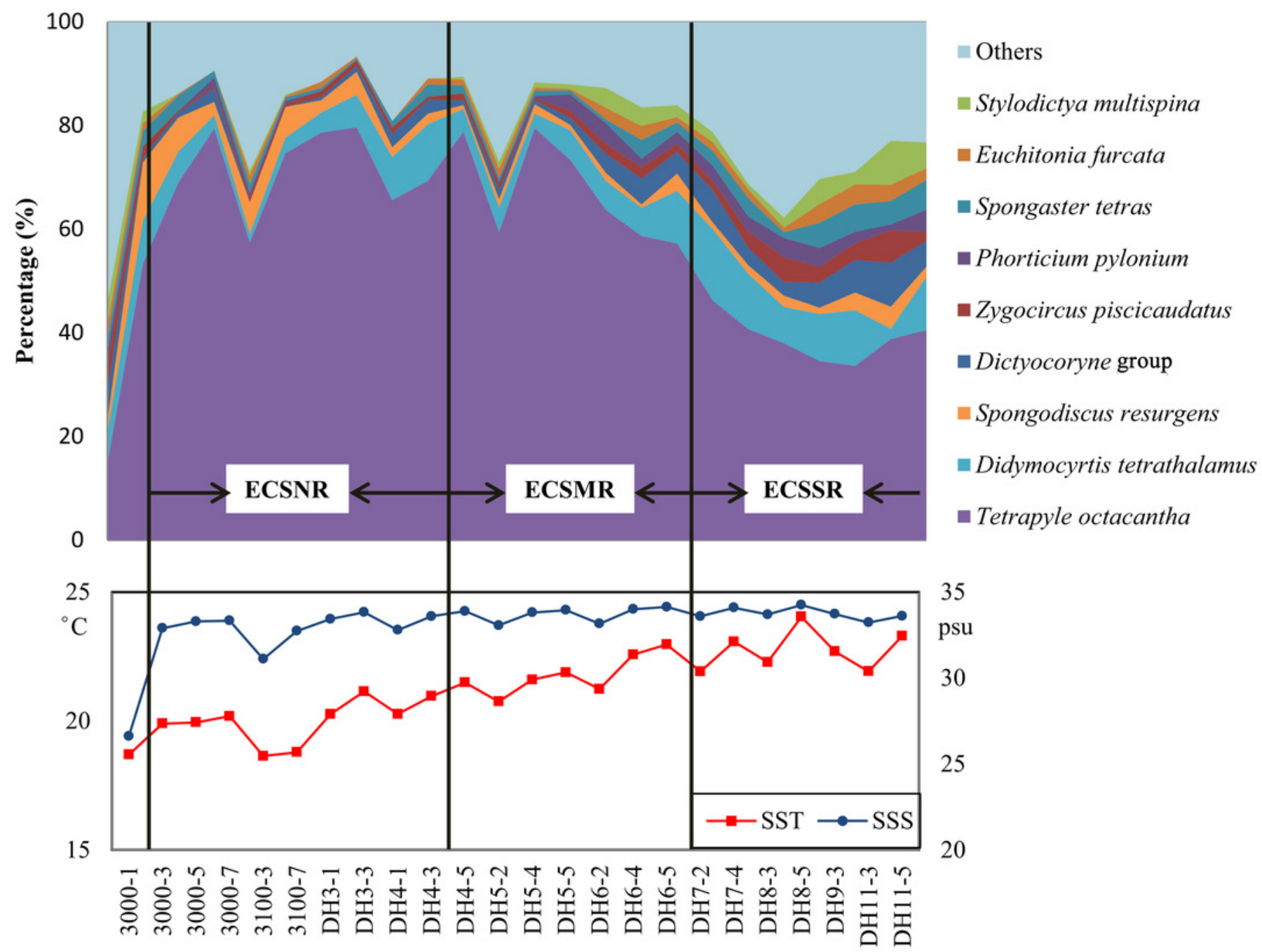




\section{Table $\mathbf{1}$ (on next page)}

The average values and standard errors (mean $\pm \mathrm{SE}$ ) of abundance and diversity indices in different regions (ECSNR, ECSMR, ECSSR).

Different lowercase $a, b$ and $c$ indicate significant differences among regional groups.

Abbreviations: $N$, Abundance (tests. $\left.(100 \mathrm{~g})^{-1}\right)$; $S$, species number; $H^{\prime}\left(\log _{\mathrm{e}}\right)$, Shannon-Wiener's index; $S_{\text {sub }}$, species number of subsamples; $H_{\text {sub }}\left(\log _{\mathrm{e}}\right)$, Shannon-Wiener's index of subsamples. 


\begin{tabular}{llll}
\hline Diversity index & ECSNR $(\mathrm{n}=9)$ & ECSMR $(\mathrm{n}=7)$ & ECSSR $(\mathrm{n}=7)$ \\
\hline$N$ & $811 \pm 121^{\mathrm{a}}$ & $2776 \pm 463^{\mathrm{b}}$ & $2729 \pm 770^{\mathrm{c}}$ \\
$S$ & $21 \pm 1^{\mathrm{a}}$ & $38 \pm 1^{\mathrm{b}}$ & $48 \pm 5^{\mathrm{b}}$ \\
$H^{\prime}$ & $1.35 \pm 0.10^{\mathrm{a}}$ & $1.61 \pm 0.13^{\mathrm{b}}$ & $2.65 \pm 0.08^{\mathrm{c}}$ \\
$S_{\text {sub }}$ & $11 \pm 1^{\mathrm{a}}$ & $16 \pm 1^{\mathrm{b}}$ & $26 \pm 2^{\mathrm{c}}$ \\
$H_{\text {sub }}^{\prime}$ & $1.22 \pm 0.11^{\mathrm{a}}$ & $1.35 \pm 0.13^{\mathrm{b}}$ & $2.43 \pm 0.10^{\mathrm{c}}$ \\
\hline
\end{tabular}

1 


\section{Table 2 (on next page)}

Average relative abundance, contribution (\%) and cumulative contribution (\%) of the radiolarian fauna contributing to the similarity within each group. A cut-off at $50 \%$ similarity was employed. 


\begin{tabular}{|c|c|c|c|}
\hline Species & Av.Abund. & Contrib \% & Cum \% \\
\hline ECSNR group & \multicolumn{3}{|c|}{ Average similarity: $64.65 \%$} \\
\hline Tetrapyle octacantha group Mueller & 69.67 & 41.70 & 41.70 \\
\hline Didymocyrtis tetrathalamus (Haeckel) & 5.65 & 9.79 & 51.49 \\
\hline Spongodiscus resurgens Ehrenberg & 4.81 & 8.89 & 60.38 \\
\hline ECSMR group & \multicolumn{3}{|c|}{ Average similarity: $66.17 \%$} \\
\hline Tetrapyle octacantha group Mueller & 67.24 & 31.00 & 31.00 \\
\hline Didymocyrtis tetrathalamus (Haeckel) & 5.54 & 8.11 & 39.11 \\
\hline Dictyocoryne group & 2.53 & 4.62 & 43.73 \\
\hline Stylodictya multispina Haeckel & 1.95 & 4.05 & 47.78 \\
\hline Spongodiscus resurgens Ehrenberg & 1.55 & 3.96 & 51.74 \\
\hline ECSSR group & \multicolumn{3}{|c|}{ Average similarity: $65.02 \%$} \\
\hline Tetrapyle octacantha group Mueller & 38.91 & 17.85 & 17.85 \\
\hline Didymocyrtis tetrathalamus (Haeckel) & 9.06 & 7.41 & 25.25 \\
\hline Dictyocoryne group & 5.26 & 5.95 & 31.20 \\
\hline Spongaster tetras Ehrenberg & 3.98 & 5.01 & 36.21 \\
\hline Zygocircus piscicaudatus Popofsky & 3.42 & 4.56 & 40.77 \\
\hline Phorticium pylonium Haeckel & 2.98 & 4.43 & 45.20 \\
\hline Stylodictya multispina Haeckel & 3.67 & 4.28 & 49.48 \\
\hline Euchitonia furcata Ehrenberg & 2.44 & 3.87 & 53.35 \\
\hline
\end{tabular}




\section{Table 3 (on next page)}

$\square \mathrm{A} \square$ Results of the RDA for the radiolarian assemblages and environmental variables. $\square \mathrm{B} \square$ Conditional effects of the total environmental variables in the RDA with the significant variables in bold. 


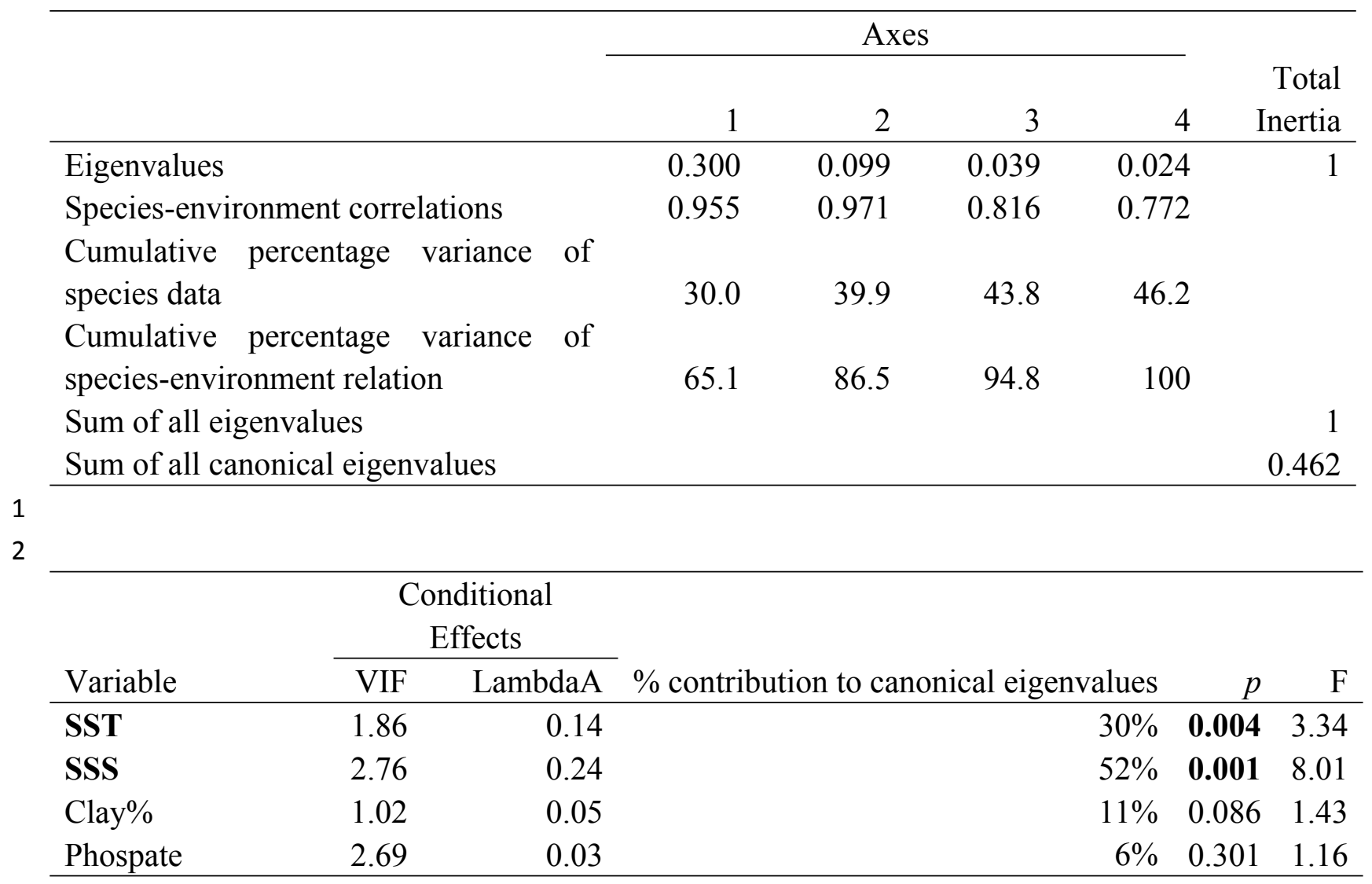

3 


\section{Table 4 (on next page)}

The Spearman correlation between diversity indices and the environmental variables. Values of significant correlations are in bold.

Different lowercase $a, b$ and $c$ indicate significant differences among regional groups.

Abbreviations: $N$, Abundance (tests. $\left.(100 \mathrm{~g})^{-1}\right)$; $S$, species number; $H^{\prime}\left(\log _{\mathrm{e}}\right)$, Shannon-Wiener's index; $S_{\text {sub }}$, species number of subsamples; $H_{\text {sub }}\left(\log _{\mathrm{e}}\right)$, Shannon-Wiener's index of subsamples. 


\begin{tabular}{|c|c|c|c|c|c|}
\hline \multirow{2}{*}{ Diversity index } & \multirow{2}{*}{$\mathrm{n}$} & \multicolumn{2}{|c|}{ SST } & \multicolumn{2}{|c|}{ SSS } \\
\hline & & $r$ & $p$ & $r$ & $p$ \\
\hline$N$ & 24 & 0.60 & 0.00 & 0.47 & 0.02 \\
\hline $\mathrm{S}$ & 24 & 0.69 & 0.00 & 0.55 & 0.01 \\
\hline$H^{\prime}$ & 24 & 0.50 & 0.01 & 0.11 & 0.62 \\
\hline$S_{\mathrm{sub}}$ & 24 & 0.60 & 0.00 & 0.28 & 0.19 \\
\hline$H_{s u b}^{\prime}$ & 24 & 0.41 & 0.04 & 0.02 & 0.92 \\
\hline
\end{tabular}

1 